\title{
Effect of inoculation with biofertiliztion, compost and foliar with fulvic On wheat growth and yield in saline soil
}

\author{
El-Sayeda H.M. El-Badawy; Nadia M. Hemeid and Sheriff, A.E.A. \\ Soil, Water and Enviro. Res. Inst., Agric. Res. Cent. Giza, Egypt
}

\begin{abstract}
Field experiment was carried out at, Qalubia Governorate, Egypt during winter season 2015 to evaluate the effect of inoculation with Bacillus ssp., compost and fulvic acid application on wheat. Results indicated that the highest increase of total count of bacteria, dehydrogenase and nitrogenase enzymes was obtained with T8 (biofertilization combined with fulvic acid and compost equal half dose of NPK) and T7(biofertilization combined with fulvic acid with equal half dose of NPK) compared with control after 60 and 90 days of planting. Also, T8 recorded the highest increase in all pigments (Chl. a, Chl. b and carotenoids) comparison with control after 60 and 90 days. Also, T8 gave the highest values in total NPK content. On the other hand, T8 induced high significant decrease in $\mathrm{Na}^{+}$content after 60 and 90 days of planting. On the other hand the low activities of catalase and peroxidase in shoot were observed in T8 compared with control. Also, proline content of shoots and roots significantly increased under salinity stress. T8 recorded the lowest value comparison with control.Also, the grain, straw yield and $\mathrm{N}, \mathrm{P}, \mathrm{K}$ in grain were highest value with $\mathrm{T} 8$ compared with control.
\end{abstract}

Key word: Wheat- Fulvic acid - Compost - Bacillus ssp( Bacillus megaterium-Bacillus subtilis )

\section{Introduction}

Salt-induced soil degradation is common in farmlands around the world, especially in arid and semi-arid regions. It has been estimated that salt has degraded more than 14.6 million hectares of farm lands across 75 countries in the past 20 years (Qadiret al. 2014). Unfortunately, farmlands are still being damaged by salt and becoming more saline due to agricultural practices such as saline water irrigation (Caoet al. 2016) and excessive fertilization (Martinez-Ballesta, et al 2010). Soil salinity is a major abiotic factor that limits the growth and development of most crop plants (Paul and Lade, 2014) in different ways such as osmotic effects, nutritional disorders and specific-ion toxicity (Läuchli and Grattan, 2007). Soil salinization, the excess accumulation of salt in the soil, often results in yield decline in agricultural production systems. Even relatively low salinity (electrical conductivity < $1.0 \mathrm{dS} \mathrm{m} 1$ ) can result in yield decline in some widely used crops such as rice and tomato (Paul and Lade, 2014). Thus, it is important to alleviate salt stress in plants in salt-affected soils during crop production.

Several approaches have been used to solve the salt stress problem, including reducing salts in soils through leaching (Zeng et al. 2014) or planting halophytes (Hasanuzzaman et al., 2014), developing salt-tolerant cultivars (Kamboj et al. 2015) and rootstocks (Albacete et al. 2015), improving salt tolerance of plants by silicon application (Zhu and Gong, 2014), and remediating salt-affected soils using organic matter conditioner (Lakhdar et al., 2011). However, it is still a challenge for scientists and farmers to seek and develop sustainable approaches which are efficient, low-cost and easily readily adaptable (Paul and
Lade, 2014). Recently, many beneficial microorganisms (BMs) have been used to alleviate salt stress and improve crop growth.

One of the major problems with saline soils is their low organic matter content, which results from rapid decomposition due to the hot and humid environment. Compost, rich in plant nutrients, is a readily available fertilizer with beneficial effects on physical, chemical and biological properties of the soils (Pane et al., 2013). Organic matter is also largely responsible for aggregation, soil moistureholding capacity, and other improved physical properties of the soil. In clay soils, it improves porosity, reduces waterlogged conditions by increasing drainage, and improves soil texture (Cook and Ellis, 1987). Increased seed germination, growth and yield are response to plant hormones, micro- and macronutrients exist in compost (Jamal and Ozra, 2014). Moreover compost can exert protective effects against plant diseases occurrence and/or stimulate and enhance plant physiological status with improvements in quantity and quality of crop production (Loredana et al., 2015). Composted organic matter also introduces the soil with vast numbers of beneficial microbes (bacteria, fungi, etc.) and augments the habitat required for maintaining microbial populations that reduce soil-borne diseases (Johnson, 1996). The healthy and active micro-flora promoted by high organic-matter content to improve soil quality. The mucilaginous by products of microorganisms stabilize soil aggregates and thus greatly improve moisture and air relationships, The $\mathrm{CO}_{2}$ given off by the organisms and the production of certain organic acids increase the capacity of the soil liquids to dissolve minerals and release potassium $(\mathrm{K})$, phosphorus $(\mathrm{P})$, calcium $(\mathrm{Ca})$, magnesium $(\mathrm{Mg})$, 
and other minerals needed by higher plants (Cook and Ellis, 1987).

Use of soil microorganisms which can either fix atmospheric nitrogen, solubilize phosphate, synthesis of growth promoting substances or by enhancing the decomposition of plant humic content of soils, will be environmentally being approach for nutrient management and ecosystem function (Wu et al., 2005). Application of biofertilizer are considered today to limit the use of mineral fertilizers and supports an effective tool for desert development under less polluted environments, decreasing agricultural costs, maximizing crop yield due to providing them with an available nutritive elements and growth promoting substances (Metin et al., 2010).

Bio-fertilizer are being essential component of organic farming are the preparations containing live or latent cells of efficient strains of nitrogen fixing, phosphate solubilizing or cellulolytic microorganisms used for application to the objective of increasing number of such micro-organisms and accelerate those microbial processes which augment the availability of nutrients that can be easily assimilated by plants. Biofertilizers play a very significant role in improving soil fertility by fixing atmospheric nitrogen, both, in association with plant roots and without it, solubilize insoluble soil phosphates and produces plant growth subsances in the soil. They are in fact being promoted to harvest the naturally available, biological system of nutrient mobilization (Venkatashwarlu, 2008).

Several plant-growth promoting rhizobacteria (PGPR) like Bacillus, Pseudomonas, Azospirillum, Rhizobium, Streptomyces, etc. have been reported to counteract salinity stress in many different plants such as wheat, rice, avocado, maize, tomato and eggplant (Paul and Lade, 2014). The above indicate that exploring the potential BMs capable of alleviating plant salt stress could be helpful for developing sustainable approaches

The ameliorative effects of PGPR on plant growth under saline conditions have been shown for various plant species, including durum wheat [Triticum durum] (Upadhyay et al., 2012). PGPR may use several mechanisms to promote plant growth and increased plant stress tolerance such as the synthesis of phytohormones like indole-3-acetic acid (IAA), gibberellic acid, or cytokinins (Spaepenet al., 2009), production of 1aminocyclopropane-1-carboxylate (ACC) deaminase (Dey et al., 2004), and production of exopolysaccharides (EPS) (Upadhyay et al., 2012).

In the present work, the effect of inoculation with bacillus. megaterium and bacillus .subtills compost and fulvic acid application on wheat growth and yield

\section{Materials and Methods}

\section{Microbial strain and culture conditions: Field experiment:}

Field experiment was conducted in Private farm, at qalubia Governorate, Egypt during winter season 2015 to study the effect of inoculation with Bacillus megateriumand Bacillus subtilis, compost and fulvic acid on wheat growth. The experiment was conducted in as complete randomized plot design with three replicated. The area of plot $2 \times 2 \mathrm{~m}$ length. The water content of the soil in each field was adjusted to $70 \%$ of WHC with irrigation water.

Seeds of wheat (Triticum aestivum cv.) Sakha 93 were obtained from Field Crop Res. Institute, Agricultural Research Center, Giza, Egypt.

Physico-chemical properties of the experimental soil were estimated according to Piper (1950) as shown in Table (1).

Table 1. Chemical and physical characteristics of the investigated soil.

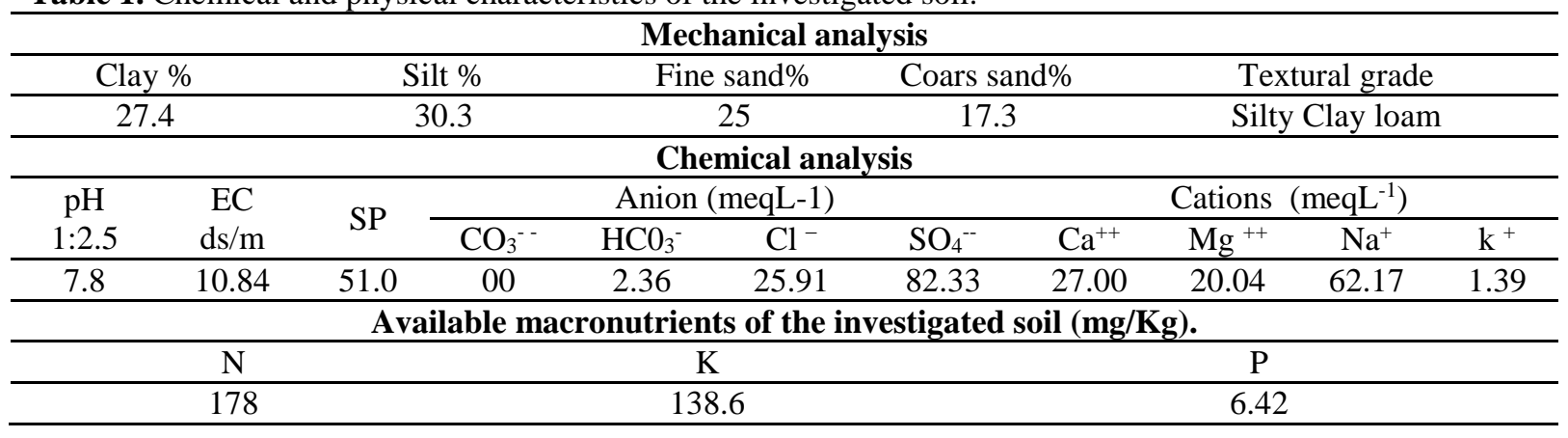

\section{Microorganisms:}

Bacillus megaterium and Bacillus subtiliswere kindly provided by Microbiology Res. Departement, Soils, Water and Environment Research Institute, ARC. Giza, Egypt. Conical flasks $(250 \mathrm{ml})$ containing $100 \mathrm{ml}$ of Nutrient broth medium (Difco,
1985) were sterilized at $121^{\circ} \mathrm{C}$ for $15 \mathrm{~min}$ and used as a growth medium. The flasks were inoculated with a loop- full of the tested strain then incubated at 28$30^{\circ} \mathrm{C}$ on rotary shaker $(150 \mathrm{rpm})$ for 2 days. Bacterial inoculants $\left(10^{9} \mathrm{CFU} / \mathrm{ml}\right)$ were added at rate of 10 L/fed. Three times at zero, 30 and 60 days. 
Table 2. Chemical analysis of compost and fulvic acid

\begin{tabular}{lclc}
\hline Paramerters & Compost & Paramerters & Fulvic acid \\
\hline Moisture $(\%)$ & 23 & T.C. $(\%)$ & 51.3 \\
\hline $\mathrm{pH}(1: 5)$ & 7.5 & $\mathrm{H}(\%)$ & 3.53 \\
\hline Total $\mathrm{N}(\%)$ & 1.1 & $\mathrm{H}: \mathrm{C}(\%)$ & 0.83 \\
\hline $\mathrm{NH}_{4}-\mathrm{N}(\mathrm{ppm})$ & 92 & $\mathrm{O}(\%)$ & 43.32 \\
\hline $\mathrm{NO}_{3}-\mathrm{N}(\mathrm{ppm})$ & 140 & $\mathrm{~T} . \mathrm{N} .(\%)$ & 2.34 \\
\hline Organic-matter $(\%)$ & 25 & $\mathrm{~S}(\%)$ & 0.76 \\
\hline Total-P $(\%)$ & 0.9 & $\mathrm{P}(\%)$ & $<0.01$ \\
\hline Total-K $(\%)$ & 1.3 & & \\
\hline
\end{tabular}

Key pH -TN - TP- TK - NO3-NH4-N- OM- T.C- H- H: C- O- S

Treatments

T1) Control full NPK\%

T2) 3 ton/fed compost $+50 \%$ NPK .

T3) $10 \mathrm{~L} / \mathrm{fed}$ Bacillus subtilis and Bacillus megaterium $+50 \%$ NPK .

T4) $10 \mathrm{~L} /$ fed fulvic acid $+50 \%$ NPK.

T5) 3 ton/fed compost +10 L/fed Bacillus subtilis and Bacillus megaterium $+50 \%$ NPK.

T6) 3 ton/fed compost +10 L/fed fulvic acid $+50 \%$ NPK.

T7) $10 \mathrm{~L} / \mathrm{fed}$ fulvic acid $+10 \mathrm{~L} / \mathrm{fed}$ Bacillus subtilis and Bacillus megaterium $+50 \% \mathrm{NPK}$.

T8) 3 ton/fed compost + 10 L/fed fulvic acid + 10 L/fed Bacillus subtilis and Bacillus megaterium + 50\% NPK.

\section{Fertilization}

The recommended doses of the chemical fertilizers ( $\mathrm{N}, \mathrm{P}$, and $\mathrm{K}$ ) full $\mathrm{NPK} \%$ were used in the control treatment according to the recommendation of Egyptian Ministry of Agriculture. Nitrogen was applied $(120 \mathrm{~kg} / \mathrm{fed})$ in the form of ammonium sulphate $(21.2 \% \mathrm{~N})$ Phosphorus, $(150 \mathrm{~kg} / \mathrm{fed})$ in the form of calcium super phosphate $\left(15.5 \% \mathrm{P}_{2} \mathrm{O}_{5}\right)$ and potassium $(100 \mathrm{~kg} / \mathrm{fed})$ in the form of potassium sulphate $\left(48 \% \mathrm{~K}_{2} \mathrm{O}\right)$.

Compost (rice straw) was added at a rate of 3 ton/fed. Organic fertilizers were added to the soil before planting.

Samples were taken for analysis after 60 and 90 days of sowing to estimated plant height, and shoot dry weight after drying at $70^{\circ} \mathrm{C}$. Macronutrients $\mathrm{Na}$, $\mathrm{P}$ and $\mathrm{K}$ were determined using felam photometer spectrophotometer according to the method described by Chapman and Pratt (1961). Total nitrogen was determined by using micro keldahl method according to Cottenie et al. (1982). Total count of bacteria in rhizosphere soil and bacillus count were counted according to the method described by Vincent (1970) and Difco (1985), respectively. Moreover, dehydrogenase activity in the rhizosphere was determined according to the method described by Squjins (1976) and nitrogenase activity was determined according to Hardy et al. (1973). The photo sythetic pigments as chlorophyll a, chlorophyll $\mathrm{b}$ and total carotenoids were detected using method described by Adams et al. (1997).

Chlorophyll stability index (CSI \%) was calculated using the formula described by Kumara et al. (2004)

$\mathrm{CSIg}=\frac{\text { Chlorophyll before stress }- \text { Chlorophyll after stress }}{\text { Cholorophyll under stress }} \times 100$

Determination of free proline content
Free proline was determined in dry shoot and root dry plant according to the method of Bates et al. (1973).

\section{Enzyme extraction and assay:}

A sample of 0.5 fresh plant was frozen, then homogenized in $8 \mathrm{ml}$ of $50 \mathrm{mM}$ cold phosphate buffer of $\mathrm{pH} 7.00$ (Beuchamp and Fridovich, 1971). The homogenates were centrifuged at 4000 $\mathrm{rpm}$ at $5^{\circ} \mathrm{Cfor} 20 \mathrm{~min}$. The supernatant was used as a raw extract for enzymatic assay. Catalase and peroxidase were assayed according to Kato and Shimizu (1987). Chemical analysis of fulvic acid was according to the method described by Hafidi, M et al (2005)

\section{Statistical analysis:}

The statistical analysis was carried out using ANOVA with two factors under significance level of 0.05 for the whole results using SPSS (ver. 22) Duncan's test was used for making a multiple comparisons among the groups for testing the intergrouping homogeneity. Data were treated as complete randomization design according to Steel $\boldsymbol{e t}$ al. (1997).

\section{Results and Discussion}

The dynamics of total bacterial populations in wheat rhizospheric roots increased during the plant growth at 60 and 90 days compared to the control (Table 3). Furthermore, data showed an increase of total bacterial population in all treatments especially with the mixture of bio fertilization and organic treatments. The highest increase of total bacterial count was recorded with T8 which recorded (2.19 and $2.74 \times 10^{8} \mathrm{CFU} / \mathrm{g}$ soil after 60 and 90 days of planting, respectively). In addition, data in Table (3) showed that, there were significant increase in the activity of dehydrogenase enzyme in all treatments, especially the combined ones compared to control, 
the highest increase value was observed in T8 which recorded 70.84 and $86.31 \mu \mathrm{g} \mathrm{TPF} / \mathrm{g}$ soil/day after 60 and 90 days of planting, respectively. Furthermore, an increase in nitrogenase activity was recorded with all treatments. T8 and T7recorded the highest values of nitrogenase which recorded 37.58 and $59.18 \mu$ mole $\mathrm{C}_{2} \mathrm{H}_{4} / \mathrm{g}$ soil/h after 60 and 90 days of planting, respectively. Dehydrogenase and nitrogenase activities in saline soil were positively enhanced by bio-inoculant combined with either compost or fulvic acid.

Table 3. Effect of inoculation with bio and organic fertilizers on total count of bacteria, dehydrogenase and nitrogenase activity in rhizosphere.

\begin{tabular}{|c|c|c|c|c|c|c|}
\hline \multirow[t]{2}{*}{ Treatments } & \multicolumn{2}{|c|}{$\begin{array}{c}\text { Total bacterial } \\
\text { count } \\
\left(\mathbf{1 0}^{8} \mathrm{CFU} / \mathrm{g} \text { soil }\right)\end{array}$} & \multicolumn{2}{|c|}{$\begin{array}{c}\text { Dehydrogenase activity } \\
(\mu \mathrm{g} \text { TPF/g soil/day) }\end{array}$} & \multicolumn{2}{|c|}{$\begin{array}{c}\text { Nitrogenase } \\
\text { activity } \\
\left(\mu \text { mole } \mathrm{C}_{2} \mathrm{H}_{4} / \mathrm{g} \mathrm{soil} / \mathrm{h}\right)\end{array}$} \\
\hline & 60 days & 90 days & 60 days & 90 days & 60 days & 90 days \\
\hline $\mathrm{T} 1$ & 0.26 & 0.47 & 19.01 & 23.74 & 8.54 & 13.51 \\
\hline $\mathrm{T} 2$ & 0.98 & 1.38 & 28.41 & 48.51 & 18.61 & 23.21 \\
\hline T3 & 1.08 & 1.43 & 30.98 & 53.58 & 24.48 & 28.49 \\
\hline $\mathrm{T} 4$ & 0.96 & 1.23 & 21.54 & 42.58 & 21.18 & 29.8 \\
\hline T5 & 1.53 & 1.89 & 38.98 & 57.34 & 29.54 & 35.00 \\
\hline T6 & 1.27 & 1.52 & 36.24 & 65.28 & 31.34 & 48.20 \\
\hline $\mathrm{T7}$ & 1.70 & 2.36 & 52.24 & 73.54 & 33.81 & 49.48 \\
\hline \multirow[t]{2}{*}{$\mathrm{T} 8$} & 2.19 & 2.74 & 70.84 & 86.31 & 37.58 & 59.18 \\
\hline & & & 1.154 & 1.367 & 1.286 & 1.318 \\
\hline
\end{tabular}

Salinity is one of the major limitations on crop productivity and quality in the world. Total count of bacteria is adversely affected by high salt concentration. Also, salinity reduced dehydrogenase and nitrogenase activities in the rhizosphere of wheat plants. Inoculation with biofertilizer, fulvic acid and compost manure succeeded to alleviate the adverse effects of salinity. But the effect of Bacillus subtilis and Bacillus megaterium plus compost was clearer. This may attributed to increase of total microbial count in soil amended with organic matter could be due to the act of simple organic carbon compounds found in compost and fulvic acid that were readily assimilated by microorganisms (Botha, 2011).

The Bacillus megaterium, which encodes $\beta$ propeller phytase. This enzyme releases phosphate residues from the inositol ring of the phytate molecule to increase phosphorus (P) uptake by plants (Jorquera et al. 2008). This process is necessary because in saline-alkaline soils, most $\mathrm{P}$ exist in insoluble forms and phytate can comprise from 10 to $50 \%$ of the total P (Mullen, 2005).

In addition Bacillus megaterium, can produced $\beta$-amylase, this enzym plays a significant role in the breakdown of starch (Scheidig et al. 2002), which is important for plants to resist abiotic stresses including salt stress.

Regarding to the data in Table (4) the addition of bio and organic fertilizers was significantly increased the plant parameters. It was clear that the plant height was significantly increased after treatments with Bacillus sp. and organic manure (T8) which recorded 23.17 and $51.28 \mathrm{~cm} /$ plant after 60 and 90 days of sowing, respectively. The same trended was observed in plant shoot dry weight, T8 recorded the highest values, which reached 3.19 and $8.02 \mathrm{~g} / \mathrm{plant}$ after 60 and 90 days of planting, respectively.

From the obtained data (Table 4) it was interested to determine pronounced increase in amount of chl a., chl b and carotenoids content in leaves of wheat plants in treatments comprise, inoculation with bio and organic fertilizers in comparison with control treatment. Therefore, T8 recorded the highest increase in all pigments, which recorded 3.826 and $7.209 \mathrm{mg} / \mathrm{g}$ dry weight for chl. a, 2.763 and $4.132 \mathrm{mg} / \mathrm{g}$ dry weight for chl. $\mathrm{b}$ and 0.904 and $2.211 \mathrm{mg} / \mathrm{g}$ dry weight for carotenoids after 60 and 90 days of sowing, respectively).

Compost and fulvic acid plus inoculation with bacillus spcaused significant higher chlorophyll stability (CS1) indices on wheat. The inoculation by bacillus in soil amended with compost caused significant higher stability indices on wheat while inoculation with bacillus sp either alone or plus compost had the least influence on (CSI) in wheat plants. Thus it's assimilate production remain undisturbed. According to Newcomb (1999) the addition of $\mathrm{N}$ to porphyrin rings of chlorophyll molecules caused temporary instability of the molecules, this could account for the higher CSI of wheat in control over treated ones. The higher (CS1) of wheat was observed in this study could be partly explained by the higher salinity resistance tolerant of wheat as reported by other workers, (Hassanein, 2000). 
Table 4. Effect of inoculation with bio and organic fertilizers on the height and weight of plants, chlorophyll and carotenoids.

\begin{tabular}{|c|c|c|c|c|c|c|c|c|c|c|}
\hline \multirow{2}{*}{$\begin{array}{l}\text { Treat- } \\
\text { ments }\end{array}$} & \multicolumn{2}{|c|}{$\begin{array}{l}\text { Plant height } \\
(\mathbf{c m})\end{array}$} & \multicolumn{2}{|c|}{$\begin{array}{l}\text { Shoot dry } \\
\text { weight } \\
\text { (g/plant) }\end{array}$} & \multicolumn{2}{|c|}{$\begin{array}{c}\text { Chl. a } \\
\text { (mg/g dry } \\
\text { weight) }\end{array}$} & \multicolumn{2}{|c|}{$\begin{array}{c}\text { Chl. b } \\
\text { (mg/g dry } \\
\text { weight) }\end{array}$} & \multicolumn{2}{|c|}{$\begin{array}{c}\text { Cartenoids } \\
\text { (mg/g dry weight) }\end{array}$} \\
\hline & $\begin{array}{c}\mathbf{6 0} \\
\text { days }\end{array}$ & $\begin{array}{c}90 \\
\text { days }\end{array}$ & $\begin{array}{c}60 \\
\text { days }\end{array}$ & $\begin{array}{c}90 \\
\text { days }\end{array}$ & $\begin{array}{c}60 \\
\text { days }\end{array}$ & $\begin{array}{c}90 \\
\text { days }\end{array}$ & $\begin{array}{c}60 \\
\text { days }\end{array}$ & 90 days & 60 days & 90 days \\
\hline T1 & 9.56 & 15.91 & 0.92 & 1.89 & 0.787 & 0.801 & 0.451 & 0.632 & 0.328 & 0.847 \\
\hline $\mathrm{T} 2$ & 17.32 & 39.82 & 1.61 & 3.86 & 1.901 & 1.931 & 0.682 & 0.785 & 0.787 & 0.831 \\
\hline T3 & 15.61 & 36.39 & 1.41 & 3.73 & 1.890 & 3.244 & 0.768 & 0.891 & 0.735 & 0.916 \\
\hline $\mathrm{T} 4$ & 14.57 & 37.43 & 1.37 & 3.59 & 1.741 & 2.544 & 0.737 & 0.832 & 0.641 & 0.739 \\
\hline T5 & 23.72 & 42.70 & 1.96 & 4.78 & 3.374 & 5.931 & 0.895 & 1.386 & 0.795 & 0.861 \\
\hline T6 & 19.26 & 40.21 & 1.71 & 3.92 & 3.182 & 5.817 & 0.831 & 1.437 & 0.826 & 1.490 \\
\hline T7 & 18.34 & 47.65 & 2.35 & 6.40 & 3.170 & 6.17 & 1.905 & 2.934 & 0.738 & 1.327 \\
\hline T8 & 23.17 & 51.28 & 3.19 & 8.02 & 3.826 & 7.209 & 2.673 & 4.132 & 1.073 & 2.197 \\
\hline L.S.D. & 0.70 & 0.17 & 0.13 & 0.04 & 0.08 & 0.435 & 0.13 & 0.63 & 0.05 & 0.10 \\
\hline
\end{tabular}

Similar results were observed in many studies in which photosynthetic pigments were significantly reduced under $\mathrm{NaCl}$ stress (Abd-Allah et al., 2015). For example, in the leaves of tomato (Hashem et al., 2015), and Bruguiera parviflora (Parida et al., 2004) the contents of chlorophyll $a$, chlorophyll $b$, and carotenoids decreased by $\mathrm{NaCl}$ stress. According to Zörb et al. (2009), the reduction in pigment content is attributed to the destructive effect of salt stress on chloroplasts in maize. PGPR strain $B$. subtilis increased chlorophyll $a, b$ and carotenoid contents in leaves of Indian bassia plants grown under both non-saline and saline soil conditions.

Mineral content under salinity stress (control treatment, T1) in wheat was significant by decreased compared to other treatments using bacteria combined with organic fertilizer (Table 5), thus $\mathrm{N}$ content was significantly increased from 1.42 and
$1.54 \%$ after 60 and 90 days of planting, respectively in the control treatment to record the highest value in T8 (1.86 and 2.04\% after 60 and 90 days of planting, respectively). Moreover, $\mathrm{P} \%$ reached 0.215 and $0.203 \%$ after 60 and 90 days of planting, respectively in the control, while $\mathrm{T} 8$ recorded the highest values 0.384 and $0.367 \%$ after 60 and 90 days of planting, respectively. Furthermore, K\% showed the same trend whereas $\mathrm{T} 8$ recorded the highest values $(2.73$ and $2.56 \%$ after 60 and 90 days of planting, respectively) in comparison with control (1.21 and $1.09 \%$ after 60 and 90 days of planting, respectively). On the contrary, $\mathrm{Na}^{+} \%$ significantly decreased in all biofertilizer and organic treatments. On the other hand, T8 induced high significant decrease in $\mathrm{Na}^{+}$ content which recorded 0.39 and $0.48 \%$ after 60 and 90 days of planting, respectively.

Table 5. Effect of inoculation with bio and organic fertilizers on mineral content of wheat.

\begin{tabular}{cccccccccc}
\hline \multirow{2}{*}{ Treatments } & \multicolumn{2}{c}{$\mathbf{N \%}$} & \multicolumn{2}{c}{$\mathbf{P \%}$} & \multicolumn{2}{c}{ K\% } & \multicolumn{2}{c}{ Na\% } \\
\cline { 2 - 10 } & $\begin{array}{c}\mathbf{6 0} \\
\text { days }\end{array}$ & $\mathbf{9 0}$ days & $\begin{array}{c}\mathbf{6 0} \\
\text { days }\end{array}$ & $\begin{array}{c}\mathbf{9 0} \\
\text { days }\end{array}$ & $\begin{array}{c}\mathbf{6 0} \\
\text { days }\end{array}$ & $\begin{array}{c}\mathbf{9 0} \\
\text { days }\end{array}$ & $\begin{array}{c}\mathbf{6 0} \\
\text { days }\end{array}$ & $\begin{array}{c}\mathbf{9 0} \\
\text { days }\end{array}$ \\
\hline T1 & 1.42 & 1.54 & 0.215 & 0.203 & 1.21 & 1.09 & 1.18 & 1.39 \\
\hline T2 & 1.69 & 1.79 & 0.284 & 0.267 & 1.85 & 1.74 & 0.49 & 0.58 \\
\hline T3 & 1.63 & 1.82 & 0.281 & 0.271 & 1.92 & 1.83 & 0.61 & 0.72 \\
\hline T4 & 1.51 & 1.63 & 0.262 & 0.241 & 1.81 & 1.69 & 0.71 & 0.78 \\
\hline T5 & 1.76 & 1.87 & 0.241 & 0.239 & 2.12 & 1.89 & 0.43 & 0.49 \\
\hline T6 & 1.69 & 1.83 & 0.309 & 0.281 & 2.20 & 1.91 & 0.53 & 0.59 \\
\hline T7 & 1.78 & 1.82 & 0.281 & 0.274 & 2.31 & 2.09 & 0.41 & 0.54 \\
\hline T8 & 1.86 & 2.04 & 0.384 & 0.367 & 2.73 & 2.56 & 0.39 & 0.48 \\
\hline L.S.D. & 0.041 & 0.049 & 0.004 & 0.0036 & 0.029 & 0.032 & 0.021 & 0.024 \\
\hline
\end{tabular}

These results confirmed with those obtained by Rashed (2002) who reported that biofertilizers combind with organic manure increased content of N, K, P of plants. Selvi et al.(2003) reported that application of organic manure increased the availability of $\mathrm{P}$ to plants. Application of compost as organic fertilizer significantly decreased $\mathrm{Na}^{+}$content in plant undergoing saline soil whereas $\mathrm{K}$ content showed an increase accordingly in plant under saline conditions. Abou El-Magd et al. (2008) confirmed that application of compost succeeded to increase the availability of $\mathrm{K}^{+}$, nitrogen and phosphorous in the whole plant. During salt stress the decrease in $\mathrm{K}^{+}$ uptake and an increase in $\mathrm{Na}+$ in flux has been 
reported by other workers (Serrano and RodriguezNavrro, 2001). In addition, increase in macronutrients uptake may be due to effect of compost and microorganisms on root surface area per unit of soil volume and water-use efficiency (El-Ghaldban $\boldsymbol{e t}$ al., 2002). Well-decomposed organic matter has a very high cation exchange capacity, which has been said to rank next to photosynthesis in importance to agriculture (Cook and Ellis 1987), and increases the buffer capacity of the soil. It can prevent or reduce leaching of substances other than cations, increasing the amounts of fertilizer that can be applied at planting time and sometimes eliminating the need for a second application (Cook and Ellis, 1987). Also, organic matter serves as a very important source of plant nutrients, including micronutrients. Although $\mathrm{N}$ and $\mathrm{P}$ in composted organic material are not always immediately available for plant growth, they are released slowly over time (Eghball, 2001). Compost application actually increases the use efficiency of mineral $\mathrm{N}$ fertilizer by crops when the two were applied in combination (Nyamangara el al., 2003).

The soil $\mathrm{pH}$ was lowered due to acidic effect of compost and other organic materials, formation of acids, release of $\mathrm{Ca}$ and leaching of $\mathrm{Na}$. These effects were more pronounced in growth of saline soils (Tiwari et al., 2001) This is an agreement with the results reported by Fathi (2010) who found that the biological amelioration methods using living or dead organic matter (green manure and compost) have two principal beneficial effects on reclamation of saline soils this enhancing the growth. Moreover, Rabia et al. (2015) who found that inoculation with cowpea plants with compost and microbial inoculation on salinity stress improved the growth plant.

On the other hand, proline content of shoots and roots of wheat were significantly decreased in all treatments (Table 6). The accumulation of proline was higher in roots than in shoots of wheat plants. Low accumulation of proline was observed in all treatments inoculated with bacteria only or supplemented with organic fertilizer. Low proline contents being 7.51 and $8.46 \mathrm{mg} / \mathrm{g}$ were detected in shoot of T8 and root, respectively) while, it reached high accumulate being 17.43 and $23.76 \mathrm{mg} / \mathrm{g}$ dry weight of shoot and root, respectively in control.

From data presented in (Table 6), it could be confirmed decrease of catalase and peroxidase activities in shoot with all tested treatment compared to the control. Inoculation with Bacuills under salinity stress decreased enzyme activity. It was interesting to note that, treatment using Bacuills supplemented with compost or fulfic acid tended to reduce catalase and peroxidase activities in shoot. Therefore, the low activities of catalase and peroxidase were observed in $\mathrm{T} 8$ which recorded 0.0394 and $2.914 \mu \mathrm{M} / \mathrm{g}$. Fr. Wt. /min, respectively.

Table 6. Effect of inoculation with bio and organic fertilizers on proline and antioxidant activity in wheat after 60 days.

\begin{tabular}{|c|c|c|c|c|}
\hline \multirow{2}{*}{ Treatments } & \multicolumn{2}{|c|}{ Proline (mg/g dry weight) } & \multirow{2}{*}{$\begin{array}{c}\text { Catalase activity in } \\
\text { shoot } \\
(\mu \mathrm{m} / \mathrm{g.fr} . w t . / \mathrm{min})\end{array}$} & \multirow{2}{*}{$\begin{array}{c}\text { Peroxidase activity } \\
\text { in shoot } \\
(\mu \mathrm{m} / \mathrm{g} . f \mathrm{r} . w \mathrm{t} . / \mathrm{min})\end{array}$} \\
\hline & Shoot & Root & & \\
\hline T1 & 17.43 & 23.76 & 0.573 & 6.371 \\
\hline $\mathrm{T} 2$ & 9.81 & 10.37 & 0.0981 & 3.357 \\
\hline $\mathrm{T} 3$ & 10.79 & 12.42 & 0.0783 & 4.378 \\
\hline $\mathrm{T} 4$ & 12.80 & 14.71 & 0.0987 & 4.143 \\
\hline $\mathrm{T} 5$ & 10.83 & 11.47 & 0.0836 & 4.081 \\
\hline T6 & 9.70 & 10.32 & 0.0729 & 3.675 \\
\hline $\mathrm{T} 7$ & 8.41 & 9.37 & 0.0482 & 3.078 \\
\hline $\mathrm{T} 8$ & 7.51 & 8.46 & 0.0394 & 2.914 \\
\hline L.S.D. & 0.435 & 0.408 & 0.0027 & 0.242 \\
\hline
\end{tabular}

According to the results of the present study, proline content of shoots and roots significantly increased under salinity stress. Non inoculated plants accumulated much proline than inoculated ones. Proline is known as the main important osmolyte accumulated under salt stress. These osmolytes play a great role for facilitating water retention in the cytoplasm and to activate water up take in growing tissues (Ashraf and Foaad, 2007). be balanced Results are similar to that obtained by Hanaa and Omar (2010) who found that when salt stressed wheat was inoculated with Bacillus sp. Proline content was significantly declined. On the contrary, Edgar et al. (2013) found positive relationship between proline concentration and inoculation with Klebsiella Pneumonia in salicornia seedlings under salinity condition. The enhancement of proline accumulation in leaves tissues was also reported with a virulent strain of Pseudomonas syringae pv. in tomato, but not with the isogonics virulent bacteria (Fabro et al., 2004). Unfavorable environmental conditions such as salinity cause increase level of reactive oxygen species (ROS) (super oxides, hydrogen peroxide). Several studies demonstrated that salt-tolerant increase their antioxidant enzymes activities and antioxidant content in response to salt stress, while salt sensitive species do not (Ashraf and Harrisb, 2004). Other studies showed a positive 
correlation between the activity of antioxidative enzymes and stress tolerance under salt stress in onion (Allium cepa) (Abd El-Baky et al., 2003). However inoculation with Bacillus sp combined with compost resulted in decreasing activities of the antioxidative enzymes (catalase and peroxidase). It was interesting to note that though a significant interaction was found, treatment with biofertilizer tended to reduce the salinity stress effect on the activity of two enzymes.

Data in Table (7) showed that the effect of orgnic and biofertilizer on yield of grain wheat by Ardab and straw Ton per feddan in saline soil. Results indicated that there is a significant difference in gain and straw yield. T8 given a high grain yield (21.37 Ardab/fed.) followed by T4, T7 and T3, while T1 had low yield (12.3 Ardab/feddan). Also, T8 given a high straw yield (2.10 ton/feddan) followed by $\mathrm{T} 6, \mathrm{~T} 2, \mathrm{~T} 5$ and $\mathrm{T} 3$, while $\mathrm{T} 1$ and $\mathrm{T} 7$ had low straw yield (1.31 and 1.34 ton/feddan).

Also, data in Table (7) revealed that there was a significant difference in percent $\mathrm{N}, \mathrm{P}$ and $\mathrm{K}$ content between all treatments. T8 had given higher content from $\mathrm{N}, \mathrm{P}$ and $\mathrm{K}$ compared other treatments, followed by T5, T7 and T3 in N, while followed by T7, T6 and T3. But, T1 had a lower content in N, P, and $\mathrm{K} \%$ compared with other treatments.

Table 7. Effect of organic and biofertilizer on yield and minerals content of wheat in saline soil (mean \pm SE).

\begin{tabular}{cccccc}
\hline \multirow{2}{*}{ Treatment } & \multicolumn{2}{c}{ Yield } & \multicolumn{3}{c}{ Macronutrients } \\
\cline { 2 - 6 } & $\begin{array}{c}\text { Grain yield } \\
\text { Ardab/feddan }\end{array}$ & $\begin{array}{c}\text { Straw yield } \\
\text { Ton/feddan }\end{array}$ & $\begin{array}{c}\mathbf{N} \\
(\boldsymbol{\%})\end{array}$ & $\begin{array}{c}\mathbf{P} \\
(\boldsymbol{\%})\end{array}$ & $\begin{array}{c}\mathbf{K} \\
(\boldsymbol{\%})\end{array}$ \\
\hline T1 & $12.30 \pm 0.23$ & $1.31 \pm 0.02$ & $1.66 \pm 0.03$ & $0.22 \pm 0.01$ & $1.33 \pm 0.01$ \\
\hline T2 & $14.30 \pm 0.17$ & $1.77 \pm 0.05$ & $1.82 \pm 0.01$ & $0.31 \pm 0.01$ & $1.82 \pm 0.02$ \\
\hline T3 & $16.67 \pm 0.20$ & $1.59 \pm 0.05$ & $1.88 \pm 0.01$ & $0.33 \pm 0.01$ & $1.90 \pm 0.01$ \\
\hline T4 & $19.63 \pm 0.61$ & $1.67 \pm 0.09$ & $1.79 \pm 0.01$ & $0.28 \pm 0.01$ & $1.74 \pm 0.01$ \\
\hline T5 & $14.50 \pm 0.29$ & $1.60 \pm 0.04$ & $2.03 \pm 0.09$ & $0.27 \pm 0.01$ & $1.96 \pm 0.02$ \\
\hline T6 & $13.37 \pm 0.23$ & $2.03 \pm 0.15$ & $1.86 \pm 0.01$ & $0.36 \pm 0.01$ & $2.06 \pm 0.07$ \\
\hline T7 & $18.17 \pm 0.17$ & $1.34 \pm 0.03$ & $1.92 \pm 0.04$ & $0.33 \pm 0.01$ & $2.47 \pm 0.09$ \\
\hline T8 & $21.37 \pm 0.23$ & $2.10 \pm 0.11$ & $2.47 \pm 0.09$ & $0.41 \pm 0.02$ & $2.93 \pm 0.15$ \\
\hline LSD & 0.90 & 0.23 & 0.15 & 0.04 & 0.20 \\
\hline
\end{tabular}

\section{Conclusion}

In view of the obtained results, it could be concluded that the inoculation of wheat with plant growth promotars bacteria in combination with compost and foliar of fulvic acid improved the growth performance of wheat and increased the productivity of grain yield under saline stress condition .Therefore, it could be recommended that the bio -inoculants and compost using for wheat production is good practice as alternative method for wheat fertilization.

\section{References}

Abd-Allah, E.F.; Abeer Hashem, A.A. Alqarawi; Bahkali A.H. and Mona S. Alwhibi(2015). Enhancing growth performance and systemic acquired resistance of medicinal plant Sesbania sesban (L.) Merr using arbuscular mycorrhizal fungi under salt stress. Saudi J. Biolo. Sci., 22 (3): 274-283.

Abd El-Baky, H.H.; Husien, M.M. and Mohamed, A.A. (2003). Influence of salinity on lipid peroxidation, antioxidant enzymes and electrophoretic patterns of protein andisoenzymes in leaves of some onion cultivars. Asian, J. Plant Sci., 2: 633-638.

Abo El-Magd, M.M.; Zaki, M.F. and AbouHussein, S.D. (2008). Effect of organic manure and different levels of saline irrigation water on growth green yield and chemical content of sweet fennel. Aust. J. Basic Appl. Sci., 2 (1): 90- 98.

Adams, B.; Adams, W. and Garce, S. (1997). Physiology of lighttolerance in plants. Hort. Rev. 18: 215-246.

Albacete, A.; Martínez-Andújar, C. ; Martínez Pérez, A.; Thompson, A.J.; Dodd, I.C. and Pérez-Alfocea , F.(2015). Unravelling rootstock $\times$ scion interactions to improve food security. J. Exp. Bot. 66:2211-2226

Ashraf, M. and Foaad, M.R. (2007). Roles of glycin betaine and proline in improving plant abiotic stress resistance. Environ. Exp. Bot., 59: 206-216.

Ashraf, M.P. and Harrisb, J.C. (2004). Potential biochemical indicators of salinity tolerance in plants. Plant Sci., 166: 3-16.

Bates, L.S.; Waldrem, R.P. and Tear, I.D. (1973). Rapid determination of free proline for water stress studies. Plant Soil, 39: 205-207.

Beuchamp, C. and Fridovich, I. (1971). Superoxide dismutase improved assays and an assay applicable to acrylamide gels. Anal. Biochem., 44: 276- 287.

Botha, A. (2011). The importance and ecology of yeasts in soil. Soil Biol. Biochem., 43: 1-8.

Cao, Y.; Tian, Y.; Gao, L. and Chen, Q. (2016). Attenuating the negative effects of irrigation with saline water on 
cucumber (Cucumis sativus L.) by application of straw biological-reactor. Agric Water Manage 163:169-179.

Chapman, H.D. and Pratt, F.P. (1961). Methods of Analysis for Soils Plant and Water. Univ. of California Div. of Agric. Sci. pp120-127.

Cook, R.L. and Ellis, B.G. (1987). Soil Management: A Worldview of Coiisenatioti and Production. Wiley: New York, pp. 152- 170.

Cottenie, A.; Verloo, M.; Velghe, M. and Camirlynck, R. (1982). Chemical analysis of plant and soil. Laboratory of Analytical and Agrochemistry . State Univ. Ghent. pp. 271276.

Dey, R.; Pal, K.K.; Bhatt, D.M. and Chauhan, S.M. (2004). Growth promotion and yield enhancement of peanut (Arachis hypogaea L.) by application of plant growth-promoting rhizobacteria. Microb. Res., 159: 371-394.

Difco Manual, (1985). Dehydrated Culture Media and Reagents for Microbiology. Laboratories incorporated Detroit, Michigan, 48232 USS. P: 621.

Edgar, O.R.; Prabhaharan, R.; Murillo-Amador, B.; Ruiz-Espinoza, F.; Puente M. and Valdez-Cepeda, R.D. (2013). Ameliorative effects of salt resistance on physiological parameters in the halophyte Salicornia bigelovii torr. with plant growth-promoting rhizobacteria. African Journal of Biotechnology. 12(34): 5278-5284.

Egh ball, B. (2001). Composting Manure and Other Organic Residue.Cooperative Extension Publication (NebGuide), Institute of Agriculture and Natural Resources, University of Nebraska, Lincoln. pp. 356-361.

El-Ghadban, E.A.; Ghallab, E.A.M. and Abdel Wahab, A.F. (2002).Effect of organic fertilizer (Biogreen) and biofertilization on growth, yield and chemical composition of marjoram plants growth under newly reclaimed soil conditions, 2nd Congress of Recent Technologies in Agriculture. 2: 334-341.

Fabro, G.; Kovacs, I.; Pavet, V.; Szabados, L. and Alvarez, H.E. (2004). Proline accumulation and AIp5CS2 gene activation are induced by plant pathogen incompatible interactions in arabidopsis. Mol. Plant- Microbe Interact. 17: 343-350

Fathi, N.O. (2010). Impact of compost on the availability and nutrients content of Vicia faba grown on saline water - irrigated soil. Minufiya. J. Agr. Res. 35 (42): 1573- 1585.

Hafidi, M.; AitBddi , G.; Gilard, V.; Ramos, p.; Alimi, k. and Revel, j. C. (2005). Charactarization of fulvic acids during olive mill waste composting (elemental, thermal and fluorescence analysis ). Chemistry and ecology volum 21, 2005 pp: 313- 424
Hanaa, A. Abo-Kora and Omar, M.N.A. (2010). Evaluation of the potential of two plant Growth Promoting Rhizobacteria (PGPR) on the increase of wheat productivity under salinity regimes. Egypt J. Microbiol. Special Issue $13^{\text {th }}$ Conf. of Microbiol., pp. 137-151.

Hardy, R.W.F.; Burns, R.C. and Holsten, R.O. (1973). Application of the acetylene ethylene assay for measurement of nitrogen fixation. Soil Biol. Biochem., 5: 47-81.

Hashem, A.; Abd Allah, E.F.; Alqarawi, A.A.; Al Whibi, M.S.; Alenazi, M.M.; Egamberdieva, D. and Ahmad, P. (2015). Arbuscular mycorrhizal fungi mitigates $\mathrm{NaCl}$ adverse effects on Solanum lycopersicum L. Pak. J. Bot., 47(1): 327-340.

Hassanein, A.A. (2000). Physiological responses induced by shock and gradual salinization in rice (Oryza sativa L.) seedlings and the possible roles played by glutathione- treatment. Acta Botanica Hungarica, 42 (1-4): 139- 154.

Hasanuzzaman, M.; Nahar, K.;Alam, M.M.; Bho wmik, P.C.; Hossain, M.A; Rahman, M.M.; Prasad, M.N.V.; Ozturk, M. and Fujita, M.(2014). Potential use of halophytes to remediate saline soils. Biomed Res Int 2014:112.

Jamal, J. and Ozra, H. (2014). Humic acid and manure Tea affected reproductive stage and fruit quality factors of pepino in organic production system, proceedlings of the 4 th ISOF SAR Scientific Conference (Building Organic Bridges ), at the Organic World Congress , 13-15 oct, Istanbul, Turkey (eprintID 23677).

Johnson, E.S. (1996). How does compost improve the Soil? Rot Web text (c): www.vegweb.com/composting/how-to.shtml.

Jorquera, M.A.; Hernández, M.T.; Rengel, Z.; Marschner, P. and Mora, M.L. (2008). Isolation of culturable phosphobacteria with both phytate-mineralization and phosphatesolubilization activity from the rhizosphere of plants grown in a volcanic soil. Biol. Fert. Soils 44:1025-1034.

Kamboj, A.; Ziemann, M. and Bhave, M. (2015). Identification of salttolerant barley varieties by a consolidated physiological and molecular approach. Acta Physiol Planta 37:1-12.

Kato, M. and Shimizu, S. (1987). Chlorophyll metabolism higher plants. VII. Chlorophyll degradation in senescing tobacco leaves: phenolic- dependent peroxidative degradation. Canada. J. Bot., 65: 729-735.

Kumara, M.; Sam, M.D.; Virnala, Y. and Pawan, A. (2004). Physiological parameters governing drought in maize indian. J. Plant Physiol., 8: 203-207. 
Lakhdar, A.; Hafsi, C.; Debez, A.; Montemurro, F.; Jedidi, N.and Abdelly, C. (2011). Assessing solid waste compost application as a practical approach for salt-affected soil reclamation. Acta Agric Scand B-Soil Plant Sci 6:284-288.

Läuchli, A. and Grattan, S. R. (2007). Plant growth and development under salinity stress. In: Jenks, M.A; Hasegawa, P.M. and Jain, S.M. (eds), Advances in molecular breeding to-ward drought and salt tolerant crops, p 1-32.

Loredana L.; Catello P.; Donatella A.; Giuseppe C.; Massimo Z. and Marisa M. (2015). Compost and Compost Tea Management of Mini Watermelon Cultivations Affects the Chemical, Physical and Sensory Assessment of the Fruits. Agricultural Sciences, 6:117-125.

Martinez-Ballesta, M.C.; Dominguez-Perles, R.; Moreno, D.A.; Muries, B.; Alcaraz-López, C.; Bastías, E.; Garc'ia-Viguera, C. and Carvajal, M. (2010).Minerals in plant food: effect of agricultural practices and role in human health. A review. Agron Sustain Dev 30:295-309.

Metin, T.A.; Medine, G.B.; Ramazan, C.C.; Taskin, O.F. and Sahin, D. (2010). The effect of PGPR strain on wheat yield and quality parameters. Proceeding of World Congress of Soil Science, Soil Solutions for a Changing World. 1-6 August 2010, Brisbane, Australia.

Mullen, M.D. (2005). Phosphorus in soils: biological interactions. In: Hillel D, editor. Encyclopedia of Soils in the Environment.Oxford: Elsevier Ltd. p. 210-215.

Nyamangara, J.; Bergstrom, L.F.; Pilia, M.I. and Giller, K.E. (2003). Fertilizer use efficiency and nitrate leaching in a tropical sandy soil, Journal of Eninronmental Quality 32: 599- 606.

Newcomb, W. (1999).Plant structure and development. In Denneis DT, Layzell, DB. Turpin DH (eds). Plant Metabolism Longman, UK. Pp.257-261.

Pane, C.; Villecco, D. and Zaccardelli, M. (2013). Short-Time Response of Microbial Communities to Waste Compost Amendment of an Intensive Cultivated Soil in Southern Italy. Communications in Soil Science and Plant Analysis, 44: 2344-2352.

Parida, A.K.; Das, A.B.; Mittra, B. and Mohanty, P. (2004). Saltstress induced alterations in protein profile and protease activity in the mangrove Bruguiera parviflora. $Z$. Naturforsch., 59: 408-414.

Paul, D. and Lade, H. (2014). Plant-growthpromoting rhizobacteria to improve crop growth in saline soils: a review. Agron Sustain Dev 34: 737-752.

Piper, G.S. (1950). "Soil and Plant Analysis". Inter. Sci. Publisher Inc. New York. USA.
Qadir, M.; Quillérou, E.; Nangia, V.; Murtaza, G. ; Singh, M.; Thomas, R.J. and Noble, A.D. (2014). Economics of salt-induced land degradation and restoration. Nat Resour Forum 38:282-295.

Rabia, B.; Batool, B.; Ansari, A.; Mustafa, S.; Ajmal, A. and Sadia Perveen, S. (2015). Amelioration of salt affected soils for cowpea growth by application of organic amendments. Journal of Pharmacognosy and Phytochemistry; 3(6): 87-90

Rashed, Nahed, M. (2002). Effect of fertilization on the growth and storability of some aromatic plants. M. Sc. Thesis, Fac. Agric. Kafer El Sheikh, Tanta Univ., Tanta, Egypt. pp: 23-28.

Scheidig, A.; Frohlich, A.; Schulze, S.; Lloyd, R. and Kossmann, J. (2002). Down-regulation of a chloroplast-targeted beta-amylase leads to starch-excess phenotype in leaves. Plant J. 30: 581-591.

Selvi, D.; Mahimairaja, S.; Santhy, P. and Rajkannan, B. (2003). Effect of organic and inorganic P fertilizers on sustainability of soil fertility and grain yield in a rice- pulse system. International Rice Research Notes. 28 (21): 4143.

Serrano, R. and Rodriguez- Navarro, A. (2001). Ion homeostasis during salt stress in plants. Cell Biology, New York, v.13: 399- 404.

Spaepen, S.; Vanderleyden, J. and Okon, Y. (2009). Plant growthpromoting actions of rhizobacteria. Advances Bot Res 51: 283-320

Squjins, J. (1976): Extracellular enzymes in soil. CRC. Cret. Rev. Microbiol., 4: 383- 421.

Steel, R.; Torrie, J. and Dickey, D. (1997). Principles and procedures of Statistics: A Biometrical Approach, $3^{\text {rd }}$ ed., McGraw-Hill, New York, NY.

Tiwari, V.N.; Singh, H. and Upadhyay, R.M. (2001). Effect of Biocides, Organic Manure and Blue Green Algae on yield and yield attributing characteristics of rice and soil productivity under sodic soil conditions. J. Ind. Soc. Soil Sci. 49(2): 332-336.

Upadhyay, S.K.; Singh, J.S.; Saxena, A.K. and Singh, D.P. (2012). Impact of PGPR inoculation on growth and antioxidant status of wheat under saline conditions. Plant Biol. 14:605-11.

Venkatashwarlu, B.(2008). Role of bio-fertilizers inorganic farming: Organic farming in rain fed agriculture: Central institute for dry land agriculture, Hyderabad, pp. 85-95.

Vincent, J.M. (1970). A Manual for practical study of the root- nodule bacteria. IBPH and book No. IS, black well Scientific Puplication Oxford. pp.89- 93.

Wu, S.C.; Cao, Z.H.; Li, Z.G. and Cheung, K.C. (2005). Effect of biofertilizer containing Nfixer, $\mathrm{P}$ and $\mathrm{K}$ solubilizers and $\mathrm{AM}$ fungi on 
maize growth: a greenhouse trial. Geoderma, 125: 155-166.

Zeng, W.; Xu, C.; Wu, J. and Huang, J. (2014). Soil salt leaching under different irrigation regimes: HYDRUS-1D modelling and analysis. J Arid Land 6:44-58.
Zhu, Y. and Gong, H. (2014). Beneficial effects of silicon on salt and drought tolerance in plants. Agron Sustain Dev 34:455-472.

Zorb, C.; Herbst, R.; Forreiter, C. and Schubert, S. (2009). Shortterm effects of salt exposure on the maize chloroplast protein pattern. Proteomics, 9: 4209-4220.

\section{تاثير التلقيح بالتسميد الحيوى والكمبوست والرش بحامض الفالبك على نمو وإنتاج القمح النامى فى ارض ملحية

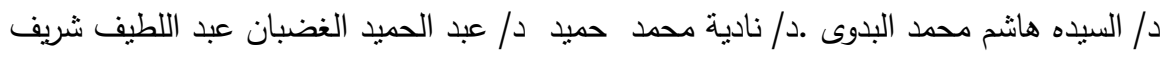 معهد بحوث الاراضى والمياه والبيئة مركز البحوث الزراعية بالجيزة - مصر}

أجريت تجربه حقلية بمحافظة القليوبية الموسم الشتوى 0 • ب لتقييم تاثير التلقيح بالمخصبات الحيوية والكمبوسـت وحامض الفالبك على القمح ولقد دلت النتائج على ان المعاملـة رقم ^ ( المخصب الحيوى + الكمبوست + حامض الفالبك + نصف جرعة التسميد المعدنى ) والمعاملة رقم V وهى الخلط بين حامض الفالبك والمخصب الحيوى سجلت اعلى النتائج بالنسبة للعدد الكلى للبكنربا ونشاط انزيم الديهيدورجينيز والنتروجنيز بعد • 7 و • 9 يوم من النمو بالمقارنة بالكنترول وسجلت ايضا المعاملة رقم 1 اعلى القيم بالنسبة لكل الصبغات وهى كلورفيل أ وكلورفيل ب والكاروتيدنات بعد • ج و • 9 يوم بالمقارنة بالكنترول وايضا سجلت المعاملة رقم ^ اعلى مستوى من النتروجين والفوسفور والبوتاسيوم فى النبات وعلى نحو اخر سجلت المعاملة رقم ^ انخفاض معنوى فى محتوى النبات من الصوديوم بعد • ج و • 9 يوم وعلى نحو اخر كان اقل نشاط لانزيمات الكتاليز والبيرو اكسيدز فى النبات مع المعاملة رقم ^ بالمقارنة بالكنترول ايضا محتوى الجذور والسيقان من البرولين زاد تحت ظروف الملوحة وسجلت المعاملة رقم 1 اقل مستوى بالمقارنة بالكنترول وايضا كان اعلى انتاج بالنسبة للحبوب والقش ومحتوى الحبوب من عناصر النتروجين والفوسفور والبوتاسيوم مع المعاملة رقم ^ بالمقارنة بالكترول 